\section{Journal of Electronic Publishing created}

Papers, documents, and your ideas about dealing with electronic publishing are sought for the Joumal of Electronic Publishing (JEP), a World Wide Web resource created by the University of Michigan. $J E P$ is designed to bring the literature on electronic publishing into one place to make finding information in this fast-moving area easier. IEP does not seek exclusivity to its papers and welcomes papers that will also be published elsewhere.

In developing $J E P$, recent pertinent papers have been collected and loaded or "pointed to." This archiving phase continues and $J E P$ welcomes additional information.

Planning is underway to enhance the resource to permit discussions centered around the ideas put forward by contributors and for guiding readers to the most significant papers. The URL of the journal is: http://www. press.umich.edu/jep. Send comments, ideas, and papers to Colin Day (colinday@umich.edu) or Lorrie LeJeune (lorrie@umich.edu).

\section{Register for ACRL by Feb. 28 and save}

Save money by advance registering for ACRL's 7 th National Conference to be held in Pittsburgh, March 29-April 1, 1995. February 28 is the deadline for advance registrations. Academic librarians find themselves in the vanguard of the movement to build a new information infrastructure. Attend this conference to stay on the cutting edge. Find out how your peers across the country are incorporating new and established technologies to enhance the teaching, learning, and research processes. Explore the many challenges facing academic librarians in the 1990 s and into the 21st century. Advance registrations are $\$ 185$ for ACRL personal

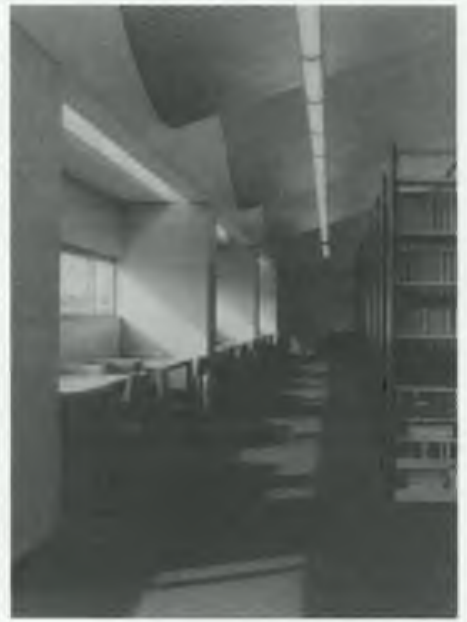

A view of study carrels in the new research library at Kent State University. members; $\$ 225$ for ALA personal members; $\$ 305$ for nonmembers; and $\$ 105$ for full-time library school students. The preliminary program was mailed to ACRL members and other academic librarians in November. The preliminary program with registration information was also published in the January 1995 issue of CERL News and is available on ALA's gopher. To access it point your gopher client to gopher.uic.edu port 70; select library, then select ALA, then Divisions, then ACRL to find the information about the National Conference. To request registration information contact Cynthia Taylor at the ACRL office at (800) 545-2433 ext. 2521 or e-mail: cynthia.taylor @ala.org.

\section{Kent State builds new math library}

The top floor of Kent State University's new \$7 million mathematics building is a 4,000-squarefoot research library. Its roof is expressed as a sine wave which is repeated in the interior linear metal ceiling. The facility, designed by the architectural firm van Dijk, Paca, Westlake \& Partners, includes group study rooms, an office work room, and circulation desk.

\section{Russian state archives will be added to RLIN}

The Research Libraries Group, Inc. (RLG), in partnership with the Hoover Institution, has developed an electronic link with the Russian State Archival Service (Rosarkhiv). Over the next two years Russian archivists will catalog Rosarkhiv materials online in RLIN (RLG's Research Libraries Information Network). Since the collapse of the Soviet Union, scholars have sought access to the long-closed records of 20thcentury Soviet history. Now these records will be available electronically through RLIN. 


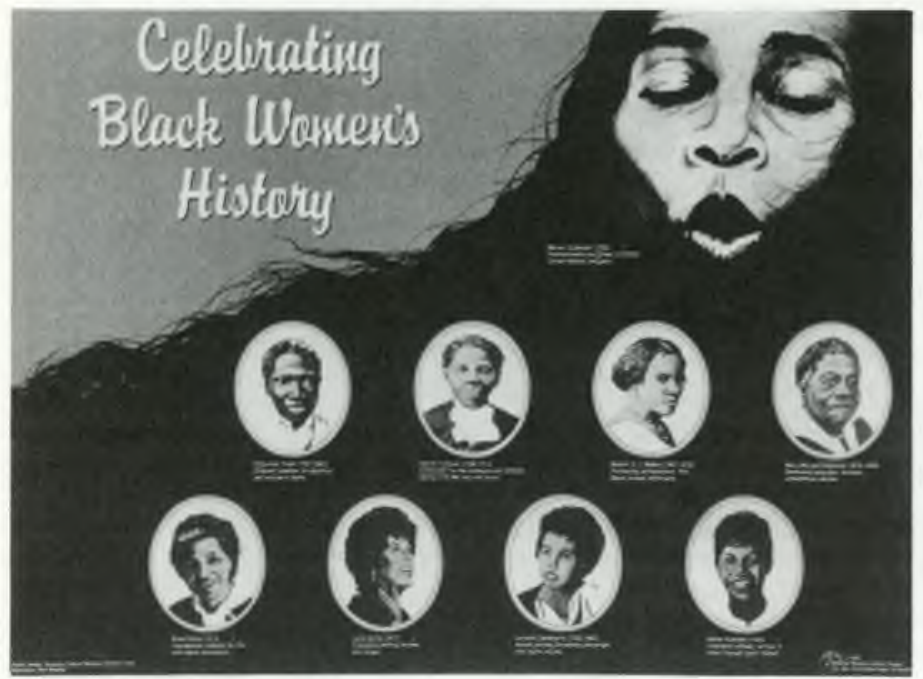

February is Black History Month and this 3-color poster celebrates black women's history by honoring nine prominent African American women: Marian Anderson, Sojourner Truth, Harriet Tubman, Madam C. J. Walker, Mary McLeodBethune, Rosa Parks, Lena Horne, Lorraine Hansberry, and wilma Rudolph. The poster is available for $\$ 6.00$ (plus $\$ 3.50$ for shipping $\&$ handling) from the National Women's History Project, 7738 Bell Road, Windsor, CA 95492.

\section{Government Printing Office expands database access}

In June of 1994, the Government Printing Office (GPO) unveiled GPO Access, an online system of databases which is the result of the GPO Electronic Information Access Enhancement Act of 1993. In its original form, GPO Access offered a single subscription to every federal depository library of each of the following databases: Congressional Record and Index, Federal Register and Index, and Enrolled Bills of the 103rd Congress.

In September of 1994, GPO announced a new program to enhance the accessibility of these databases through GPO Access Gateways, which originally included six university libraries and one public library. This program was expanded in October of 1994 to include any library willing to sign on and support a Gateway. Unlike GPO Access as it was originally proposed, which supplied access to the databases for only one user from one IP address, the Gateways will support multiple users simultaneously from one site. In addition to expanding the availability of GPO Access, GPO has also announced that the number of databases will expand. The United States Code has recently been added, as has the database that will contain the bills of the 104th Congress. GPO hopes to add the Code of Federal Regulations and the Government Information Locator in the near future.
Here are the GPO Access Gateways currently in operation and how to access them:

COIN: Telnet 128.206.1.3 or dial (314) 8847000; login as GUEST; Main Menu select "Government Center"; select GPO ACCESS.

Seattle Public Library: Telnet 198.137. 188.2 or dial (206) 386-4140; login as library (lower case); select VT100; select Internet twice; from Gateways menu select GPO Access.

Georgia Southern University: Telnet gsvms2.cc.gasou.edu or dial into GSnet (9600 baud) at (912) 681-0005; modem settings are 8 data bits, no parity, 1 stop bit; terminal emulation VT100; press < Enter > twice; from GSnet prompt enter: connect gsvms2; login as Info; select Government Printing Office Access; users with slower modems may dial into PeachNet at (912) 681-0500; at the PeachNet prompt enter: connect gsvms2.cc.gasou.edu.

Penn State University: Telnet lias.psu.edu or dial (814) 865-5427; communication settings are full duplex, no parity, 8 bits, 1 stop bit; VT100 emulation is recommended. For dial access: when connection is established press $<$ Enter $>$ once. For dial access and Internet access: respond to prompts for terminal emulation and user ID (press < Enter>); at LIAS screen type: Select; from Select menu choose GPO Access; to exit LIAS, type exit.-Maurie Caitlin Kelly, University of Illinois at Chicago 
In exchange for Russia's contribution to RLIN, the 67 million records already in the RLIN database will be available to scholars in Russia. The cataloging and access project, supported by a grant to the Hoover Institution from the National Endowment for the Humanities, will develop a system for cataloging archival materials located in four Russian repositories that includes standards and a methodology for sharing information on RLIN.

\section{Africana file available on Internet}

The machine-readable version of the data used to produce the Joint Acquisitions List of Africana ( $J A L A)$ has been mounted on Michigan's MIRLYN system and is available to all users via the Internet. "Northwestern University's African Library began the file in the 1960 s and continues to be a repository for these records," reports David Easterbrook, curator of the Melville J. Herskovits Library of African Studies at Northwestern. " $J A L A$ in its paper format is published bimonthly and received by libraries worldwide that have an interest in African studies. For the library community with access to the Internet, this file provides a major improvement for locating Africana materials across the country."

"AFRI, the name of the African file, is accessible under the 'Indexes' section on MIRLYN's first menu," states William Gosling, assistant director for technical services and library systems at the University of Michigan. With more than 111,400 records available, researchers can find information about Africana materials and where they are located. Each citation contains a minimum of one holding location.

The file contains the Africana collections of 19 research libraries including Indiana University, the University of California-Los Angeles, Yale University, and the Library of Congress.

\section{New book banishes stereotypes}

Discovering Librarians: Profiles of a Profession, edited by Mary Jane Scherdin and published by ACRL, will help correct the misconceptions of those who may hold negative stereotypes of librarians. It presents national study results on vocational interests of library and information professionals to develop a more accurate picture of the interests, skills, and personality of the typical librarian. Twelve chapters examine updated profiles of li- brarians that have been developed according to widely used interest tests, such as the ACT Interest Inventory, the Campbell Interest and Skill Survey, and the SIGI PLUS computer-aided career guidance tool. An analysis of demographic data is also included. Discovering $\mathrm{Li}$ brarians (ISBN 0-8389-7753-7) is available for $\$ 35.95$ ( $\$ 31.95$ ACRL members) from the American Library Association, Order Fulfillment, 520 N. Dearborn, Chicago, IL 60610. For faster service, orders may be phoned in to (800) 545 2433 or faxed to (312) 836-9958.

\section{University of Oregon expands library}

The University of Oregon's Knight Library has completed a three-year building and renovation project that melded the original 1937 structure (listed on the National Register of Historic Places) with 1950 and 1966 additions and the 1994 expansion. The $\$ 27.4$ million project added more than 135,000 square feet to the 237,000 square-foot library; tripled student seating capacity; increased shelving space by about $27 \%$; added 22 new group-study and seminar rooms; updated facilities for computerized instruction and guided research; expanded the Instructional Media Center to include state-of-the-art distance learning classrooms; modernized the heating, cooling, lighting, and ventilation systems for

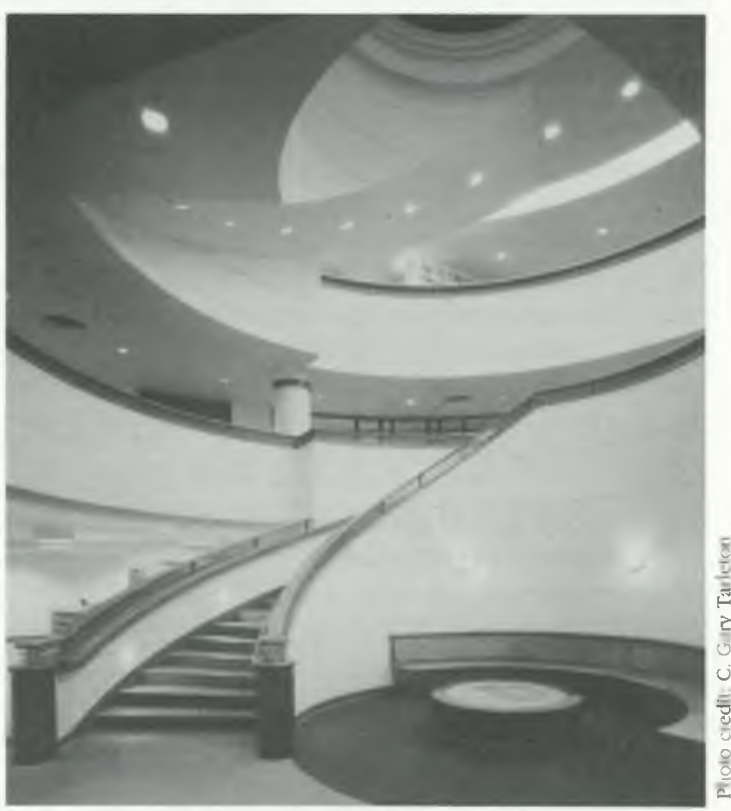

The Solari South Stair Gallery at the University of Oregon's newly expanded Knight Library. 


\section{ACRL electronic communications}

ACRL and its units are establishing a number of electronic listservs and resources to facilitate communication among members. Here is a list of known electronic resources sponsored by ACRL units. Please notify Mary Ellen Davis of any additions, changes, or corrections that need to be made. Her e-mail address is mary.ellen.davis@ala.org.

\section{ACRL Forum}

Name of list: ACRL-FRM

To subscribe send the message:

"Subscribe ACRL-FRM your name" to listserv@uicvm.uic.edu

Address: ACRL-FRM@uicvm.uic.edu

\section{ACRL Gopher and C\&RL NewsNet}

Point your gopher client to gopher.uic.edu, port 70; select "The Library," then select either "AL.A" to find ACRL information, or "C\&RL NewsNet" to read an abridged version of the magazine

\section{Afro-American Studies Librarian (AFAS) \\ Name of list: AFAS-L \\ To subscribe send the message: \\ "Subscribe AFAS-L your name" to \\ LISTSERV@KENTVM.KENT.EDU \\ Address: AFAS-L@KENTVM.KENT.EDU}

increased user comfort and to protect library materials; provided handicapped access to the building; and allowed for future expansion. TBG Architects and Planners in Eugene were the lead architects. One-third of the cost of the project was funded by private gifts and grants.

\section{New ACRL book offers employee management assistance}

A new publication in ACRL's CLIP (College Library Information Packet) Note series provides useful guidance for managing student employees, who represent an average of over $25 \%$ of staff in college libraries. Managing Student Employees in College Libraries, CLIP Note 20 surveys employee management practices of 150 college libraries and includes excerpts from policies and procedures manuals covering a

\section{Anthropology and Sociology (ANSS)}

Name of list: ANSS-L

To subscribe send the message:

"Subscribe ANSS-L your name to

LISTSERV@UCI.EDU

Address: ANSS-L@UCI.EDU

\section{Asian, African, and Middle Eastern}

(AAMES)

Name of list: ACRL-AAMES

To subscribe send the message:

"Subscribe ACRL-AAMES your name" to

LISTPROC@MCFEELEY.CC.UTEXAS.EDU

Address: ACRL-AAMES@MCFEELEY.CC.

UTEXAS.EDU

\section{Community and Junior College Libraries} (CJCIS)

Name of list: CJC-L

To subscribe send the message:

"Subscribe CJC-L your name" to

LISTSERV@Dekalb.dc.peachnet.edu

Address: CJC-I@DEKALB.DC.PEACHNET.EDU

\section{College Libraries (CIS)}

Name of list: COLLIB-L

To subscribe send the message:

"Subscribe COLLIB-L your name" to

LISTPROC@WILLAMETTE.EDU

Address: Collib-L@willamette.edu

wide range of employee management issues. Examples include job description and application forms, interviews and reference checking, employee agreements, and dismissal procedures. Managing workers on the job is also covered in sections dealing with orientation, training, supervision, evaluation, and performance review.

Managing Student Employees (ISBN 0-83897752-9) was compiled by Michael D. Kathman and Jane McGurn Kathman under the auspices of the ACRL College Libraries Sections' CLIP Notes Committee. It sells for $\$ 29.95$ ( $\$ 25.95$ to ACRL members) and is available from the American Library Association, Order Fulfillment, 520 N. Dearborn, Chicago, IL 60610. For faster service, orders may be phoned in to (800) 5452433 or faxed to (312) 836-9958. 


\section{Discussion Group on Electronic Text Centers}

Name of list: ETEXTCTR

To subscribe send the message:

"Subscribe ETEXTCTR your name" to

LISTSERV@rutvm1.rutgers.edu

Address: ETEXTCTR@rutvm1.rutgers.edu

\section{Education and Behavioral Sciences (EBSS)}

Name of list: EBSS discussion list

To subscribe send the message:

"Subscribe to the EBSS discussion list your name" to

ROLLINS@MAINE(bitnet)

Address: ROLLINS@MAINE.MAINE.EDU

(Note: do not use listserv commands)

\section{Exhibits and Displays in Libraries}

Name of list: LIBEX-L

To subscribe send the message:

"Subscribe LIBEX-L your name" to

LISTSERV@MAINE.MAINE.EDU

Address: LIBEX-L@MAINE.MAINE.EDU

\section{Extended Campus Library Services (ECLSS)}

Name of list: Off Camp

To subscribe send the message:

"Subscribe Off Camp your name" to

OffCamp@Waynest 1

Address: OffCamp@Waynest1

\section{Fee-based Information Services Centers} in Academic Libraries

Name of list: FISC-L

To subscribe send the message:

"Subscribe FISCL your name" to

LISTSERV@NDSUVM1.bitnet

Address: FISC-L@NDSUVM1.bitnet

\section{Update on information literacy data}

The January "News from the Field" column reported on ACRL entering into a cooperative research project for the purpose of collecting data on existing information literacy programs in higher education institutions across the U.S.

"It is important for the library profession to involve key organizations and individuals outside the profession in a discussion about the value of an information-literate society," said ACRL vice-president Patricia Senn Breivik.

Survey forms were mailed to college and university campuses requesting information on

\section{Law and Political Sciences (LPSS)}

Name of list: LPSS-L

To subscribe send the message:

"Subscribe LPSS-L your name" to

LISTSERVER@lists.acs.ohio-state.edu

Addrexs: LPSS-L@LISTS.ACS.OHIO-STATE.EDU

\section{Racial \& Ethnic Diversity Committee}

Name of list: EQUILIBRN

To subscribe send the message:

"Subscribe EQUILIBRN your name" to

LISTSERV@FULLERTON.EDU

Address: EQUILIBRN@FULLERTON.EDU

\section{Science and Technology (STS)}

Name of list: STS-L

To subscribe send the message:

"Subscribe STS-L your name" to

LISTSERV@UTKVM1.UTK.EDU

Address: STS-L@UTKVM1.UTK.EDU

\section{Science and Technology (STS)}

Name of publication: Issues in Science \&

Technology Librarianship (ISTL)

To subscribe send a request to:

ACRLSTS@HAL.UNM.EDU

\section{Western European Specialists (WESS)}

Name of list: ECOLL.

To subscribe send the message:

"Subscribe ECOLL your name" to

LISTSERV@UNLLIB.UNL.EDU

Address: ECOLL@UNLLIB.UNL.EDU

\section{Western European Specialists (WESS)}

Name of list: DISC-NORDLIB

To subscribe send a message (be sure to include your e-mail address) to:

disc-nordlib-request@mail.unet.umn.edu

Address: DISC-NORDLIBt@mail.unet.umn.edu

current programs dealing with information literacy. More than 200 responses have been received so far. The results from the data collection will be shared in a series of articles in a wide range of journals, and in a series of regional "best-practice" workshops, and eventually in a major book-length publication combining the knowledge gained through the surveys and the workshops. This project has the endorsement of the American Association of Higher Education (AAHE), which is committed to disseminating the results to its membership. 